\title{
PENGARUH MAJALAH ILMIAH KAMPUS PENGAWASAN TERHADAP PENINGKATAN PENGETAHUAN DAN SIKAP APIP TERHADAP FRAUD, SERTA CITRA PUSDIKLATWAS BPKP
}

\author{
The Effect of Kampus Pengawasan Scientific Magazine to APIP's \\ Knowledge and Attitude Enhancement about Fraud, and Pusdiklatwas \\ BPKP's Image \\ Dian Setyawati ${ }^{1}$, Amiruddin Saleh $^{2}$, Musa Hubeis ${ }^{3}$ \\ ${ }^{1}$ Biro Hukum dan Humas BPKP \\ ${ }^{2}$ Departemen Sains Komunikasi dan Pengembangan Masyarakat Fakultas Ekologi \\ Manusia IPB \\ ${ }^{3}$ Departemen Manajemen Fakultas Ekonomi dan Manajemen IPB \\ e-mail: diansetyawati79@gmail.com
}

\begin{abstract}
APIP is an internal government supervisory agency with the strategic function, but its capabilities are still to be improved. Especially the auditor's competence to prevent and detect fraud. Pusdiklatwas BPKP in supporting the mission of the organization and maintain also enhance the image of the organization, has published a scientific magazine Kampus Pengawasan (KP). The purpose of this study is (1) to test the effect of the use of media magazine KP to change knowledge and attitudes APIP about fraud, (2) test the effect of media usage Magazine KP to the image of the organization, (3) analyze the effect of the characteristics of the reader, the information needs, assess the effectiveness of magazines and selectivity to improve the knowledge and attitudes APIP about fraud and the organization's image. This research uses quasy experimental method with a pretest and posttest nonekuivalen group design. Respondents in this study were 80 auditors from the Inspektorat office throughout Indonesia who are following the training program in Pusdiklatwas BPKP. The research proves that the scientific magazine KP significantly influence the rising effect of the magazine in the form of knowledge and attitudes APIP about fraud but does not significantly affect the organization's image enhancement both image institution and the teacher's image. Other variables that contributed significantly affect the influence of the magazine is characteristic of the reader, the assessment of effectiveness and selectivity while the organization's image is affected by characteristic of the reader.
\end{abstract}

Key words: attitudes, effect, fraud, image, knowledge, scientific magazine.

\section{ABSTRAK}

Aparat Pengawas Intern Pemerintah (APIP) adalah agensi pengawas internal pemerintah dengan fungsi strategis, tetapi kapabilitasnya masih perlu ditingkatkan. Khususnya pada kompetensi auditor untuk mencegah dan mendeteksi kecurangan. Pusat Pendidikan dan Pelatihan Pengawasan Badan Pengawasan Keuangan dan Pembangunan (Pusdiklatwas BPKP) dalam mendukung misi dari organisasi dan mengelola juga meningkatkan citra dari organisasi, telah mempublikasikan majalah ilmiah Kampus Pengawasan (KP). Tujuan dari penelitian ini adalah (1) untuk menguji efek penggunaan media Majalah KP untuk meningkatkan pengetahuan dan sikap APIP mengenai kecurangan, (2) menguji efeka menggunaan media Majalah KP untuk citra organisasi, (3) menganalisa efek dari karakteristik pembaca, informasi yang dibutuhkan, menilai efektivitas majalah dan selektivitas untuk meningkatkan pengetahuan dan sikap APIP mengenai kecurangan dan 
citra organisasi. Penelitian ini menggunakan metode kuasi eksperimental dengan desain pengujian sebelum dan sesudah secara non ekuivalen pada kelompok. Responden pada penelitian ini adalah 80 auditor dari kantor inspektorat dari seluruh Indonesia yang mengikuti pelatihan program di Pusdiklatwas BPKP. Peneliti menemukan bahwa majalah ilmiah KP secara signifikan mempengaruhi peningkatan efek pengetahuan dan sikap APIP tentang kecurangan tetapi tidak secara signifikan mempengaruhi peningkatan citra organisasi baik cintra institusi dan citra pengajar. Variabel lainnya yang berkontribusi secara signifikan adalah karakteristik pembaca, penilaian efektivitas dan selektivitas majalan ketika citra organisasi dipengaruhi oleh karakteristik dari pembaca.

Kata Kunci: sikap, efek, kecurangan, citra, pengetahuan, majalah ilmiah.

\section{PENDAHULUAN}

\section{Latar Belakang}

Dalam upaya peningkatan transparansi dan akuntabilitas sebagai bagian dari sembilan Program Percepatan Reformasi Birokrasi, penguatan peran Aparat Pengawas Intern Pemerintah (APIP) menjadi penting untuk dikedepankan. Sesuai Peraturan Pemerintah (PP) No 60 Tahun 2008, lembaga APIP yang terdiri dari Badan Pengawasan Keuangan dan Pembangunan (BPKP), Inspektorat Jenderal pada kementerian/lembaga, Inspektorat Provinsi, Kabupaten dan Kota mempunyai peran seperti: memberikan keyakinan yang memadai atas ketaatan, kehematan, efisiensi, dan efektivitas pencapaian tujuan penyelenggaraan tugas dan fungsi instansi pemerintah; memberikan peringatan dini dan meningkatkan efektivitas manajemen risiko dalam penyelenggaraan tugas dan fungsi instansi pemerintah; serta memberikan masukan yang dapat memelihara dan meningkatkan mutu tata kelola penyelenggaraan tugas dan fungsi instansi pemerintah.

Berdasarkan pendekatan Internal Auditor Capability Model (IACM), kondisi saat ini menunjukkan secara keseluruhan $85.23 \%$ atau 404 unit kerja masih berada di Level 1. Hal ini berarti APIP belum dapat memberikan jaminan atas proses tata kelola sesuai peraturan dan belum mampu mencegah korupsi; 14.56 persen atau 69 unit kerja APIP mencapai Level 2, dimana APIP mampu memberikan keyakinan yang memadai, proses sesuai dengan peraturan dan mampu mendeteksi terjadinya korupsi. Hanya 0.21 persen atau satu unit kerja APIP yang telah mencapai Level 3 dimana APIP telah mampu menilai efisiensi, efektivitas ekonomis suatu kegiatan dan mampu memberikan konsultasi pada tata kelola, manajemen risiko dan pengendalian intern. Hingga kini belum terdapat unit kerja APIP yang mampu mencapai Level 4 dimana APIP telah mampu memberikan jaminan secara keseluruhan atas tata kelola, manajemen risiko dan pengendalian intern serta Level 5 dimana APIP mampu menjadi agen perubahan (Simanjuntak 2015).

Beberapa penyebabnya, antara lain jumlah auditor saat ini baru berjumlah 12.755 orang atau $(27,39 \%)$ dari total kebutuhan nasional 46.560 orang sehingga terjadi kekurangan 33.805 orang. Selain itu, kompetensi dan profesionalisme sumber daya manusia (SDM) belum memadai, seringnya mutasi tanpa kaderisasi, sehingga menunjukkan kurangnya komitmen pimpinan dalam memberdayakan 
APIP, anggaran dan sarana Teknologi Informasi (TI) belum memadai, maupun perencanaan yang belum berdasarkan prioritas/risiko (Simanjuntak 2015).

Kompetensi menjadi faktor nyata dalam mendukung kinerja APIP. Erina et al. (2012) menyimpulkan kompetensi secara parsial maupun bersama-sama peubah integritas, obyektivitas, dan kerahasiaan berpengaruh terhadap kinerja APIP. Salah satu kompetensi yang harus dimiliki APIP adalah kemampuan mendeteksi kecurangan (fraud). Berdasarkan data dari tahun 2009-2013 BPKP telah membantu Kejaksaan, Kepolisian dan Komisi Pemberantasan Korupsi (KPK) dalam menghitung dugaan kerugian keuangan negara akibat korupsi (fraud) yaitu Rp10.149 triliun (Mardiasmo dalam Anugerah 2014). Hal tersebut menunjukkan masih tingginya penyimpangan keuangan negara yang terjadi sehingga APIP dituntut mempunyai tanggung jawab yang kuat dalam mendeteksi fraud. Fuad (2015) meneliti persepsi auditor pada kantor BPK dan BPKP Provinsi Jawa Tengah mengenai tanggung jawab dalam mendeteksi fraud dan menyimpulkan bahwa faktor independensi dan kompetensi berpengaruh positif terhadap tanggungjawab auditor dalam mendeteksi kecurangan.

Salah satu unsur penting dalam mendukung profesionalisme auditor internal adalah tersedianya majalah/jurnal yang berisi perkembangan pengetahuan teknis maupun artikel bermanfaat dalam bentuk features (Pickett 2003). Media seperti ini penting dalam membangun profesionalisme anggota, karena melalui media tersebut anggota dapat menyampaikan hasil penelitian, pemikiran dan pengalaman yang masih berkaitan dengan a common body of knowledge profesi. Dengan demikian terbangun transfer knowledge dan berbagi informasi yang kuat antar anggota profesi, hingga setiap anggota dapat memperoleh pengetahuan terkini di bidangnya (Wibowo 2012).

Jurnal internal merupakan media yang diciptakan sendiri oleh organisasi/perusahaan untuk menjangkau khalayak tertentu dalam rangka mencapai tujuan-tujuan Public Relations (PR). Publikasi yang didistribusikan kepada para anggota ataupun khalayak pendukung dari suatu organisasi seperti institusi-institusi profesional, universitas, komunitas profesi tertentu, serikat buruh, dan yayasan amal lazim disebut jurnal internal semi-eksternal (Jefkins \& Yadin 2014). Menurut Prawati (2003), majalah ilmiah merupakan terbitan berkala, terbit terus-menerus dengan judul majalah yang sama, untuk jangka waktu yang tidak dapat ditentukan dan dengan waktu terbit tertentu pula. Setiap nomer terbitan memuat beberapa tulisan atau artikel, bisa dengan topik yang sama atau berbeda. Teks artikel tidak sepanjang teks buku, sehingga ide pokok penulis lebih mudah ditangkap.

Prawati (2003) menyatakan majalah ilmiah berisi temuan dan ide baru, diterbitkan oleh organisasi atau sekelompok orang yang membentuk perhimpunan dan dikelola oleh suatu tim redaksi tertentu. Majalah memiliki sistem kontrol internasional, yaitu International Standard Serial Number (ISSN). Majalah juga merupakan media penyebaran informasi di antara ilmuwan, melalui media ini dapat dikenal siapa mengetahui siapa, serta orang-orang yang ahli dalam suatu bidang profesi tertentu. Artikel yang dimuat dalam majalah ilmiah biasanya merupakan hasil dan temuan baru penelitian, isinya penuh dengan 
nada keorisinilan tinggi, sehingga hanya menjadi arena komunikasi pakar atau ilmuwan spesialis (Rifai dalam Tambunan 2014).

Beberapa hal yang terkait dengan karakteristik APIP selain umur, jenis kelamin, pendidikan dan penghasilan adalah komitmen organisasi, komitmen profesi dan motivasi meningkatkan kompetensi. Bagia et al. (2015) menyatakan komitmen organisasi merupakan perwujudan dari kerelaan seseorang dalam bentuk pengikatan diri dengan organisasi yang digambarkan oleh besarnya usaha (tenaga, waktu, dan pikiran) atau semangat belajar yang berkelanjutan untuk mencapai visi bersama. Komitmen organisasi sangat penting dan diperlukan dalam organisasi karena karyawan yang memiliki komitmen tinggi pada organisasi akan cenderung memiliki sikap profesional dan menjunjung tinggi nilai-nilai yang telah disepakati.

Komitmen profesional adalah tingkat loyalitas individu pada profesinya seperti yang telah dipersepsikan oleh individu tersebut. Agar seseorang dapat berperilaku dengan baik, maka harus memperhatikan etika profesional yang diatur dalam kode etik. Etika profesional adalah standar perilaku seseorang profesional yang dirancang untuk tujuan praktis dan idealistik, sehingga mendorong perilaku seseorang yang ideal, bersifat realistis, dan dapat dipertanggungjawabkan secara hukum (Tranggono \& Kartika 2008).

Gibson dalam Tranggono \& Kartika (2008) menyatakan bahwa motivasi merupakan hal yang mendorong individu ataupun kelompok untuk melakukan sesuatu perbuatan, baik itu faktor dari dalam diri individu maupun faktor dari luar. Santrock dalam Bagia et al. (2015) melihat ranah motivasi ada dua, yaitu: (1) motivasi intrinsik adalah keinginan dari dalam diri seseorang untuk melakukan sesuatu bermanfaat bagi dirinya; dan (2) motivasi ekstrinsik adalah keinginan untuk melakukan sesuatu yang lebih dipengaruhi oleh faktor-faktor yang berasal dari luar dirinya. Di samping itu, Rianto dalam Bagia et al. (2015) juga mengungkapkan bahwa motivasi adalah sesuatu hal yang merubah kita dari rasa jenuh menjadi rasa tertarik yang juga memberi semangat dan membimbing aktivitas. Motivasi untuk meningkatkan kompetensi dapat diartikan sebagai keinginan yang mendorong individu untuk meningkatkan kompetensinya, baik berasal dari dalam dirinya maupun dari luar dirinya.

Bauer dalam Sardi (2012) mengatakan ada beberapa sifat masyarakat yang memengaruhi kebiasaan berinformasi dan relevan untuk memahami efek komunikasi. Satu di antaranya intuisi kebutuhan (need cognition), suatu kebutuhan yang amat dekat hubungannya dengan rasa ingin tahu. Informasi dibutuhkan pengguna bertujuan untuk menambah pengetahuan dan meningkatkan keterampilan yang dapat mengubah sikap dan perilakunya (Sankarto dan Permana dalam Sardi 2012).

Bertrand (1978) menyatakan sebuah media dalam mencapai efektifitas dalam penyampaian pesan sesuai tujuan yang diharapkan harus memenuhi unsur yaitu : (1) daya tarik (attraction), sebuah media harus mampu mendesain pesan yang menarik perhatian dan disukai target audiens; (2) pemahaman (comprehension), desain pesan juga harus mudah dipahami oleh target audiens; (3) penerimaan (acceptability) desain pesan juga harus menghindari hal-hal 
bertentangan dengan nilai-nilai yang berlaku pada suatu daerah atau komunitas, sehingga dapat diterima dengan baik; (4) keterlibatan diri (self involvement), desain pesan juga harus mampu menjadikan target audiens merasa terlibat dalam topik yang diulas.

Melvin DeFleur dalam Black et al. (1998) menyatakan studi mengenai persepsi manusia menemukan bahwa nilai-nilai individu, kebutuhan, keyakinan dan sikap merupakan unsur yang memengaruhi bagaimana seseorang akan memilih stimulus dari meningkatnya media dan dalam mengartikan stimulus tersebut. Selanjutnya, DeFleur menyimpulkan perhatian selektif dan terpaan selektif dipengaruhi mekanisme psikologis yang memodifikasi model stimulus respon pada komunikasi massa. Individu diketahui akan memilih pesan berkaitan dengan minat, konsisten dengan keyakinan dan mendukung nilai-nilai yang dianutnya. Sama halnya dengan temuan individu yang menghindari pesan yang bertentangan dengan minat, sikap, keyakinan dan nilai yang dianut.

Denham (2006) menyatakan media mempunyai kapasitas untuk memengaruhi pengetahuan dan sikap mengenai bahaya penggunaan doping, namun sebaiknya lebih menekankan kepada fakta ilmiah. Penelitian Pankratow et al. (2013) membuktikan konsumsi media khususnya pesan melalui majalah kesehatan mampu mempengaruhi motivasi berolahraga untuk alasan kesehatan tidak hanya untuk mencapai bentuk tubuh yang sempurna.

Nova (2011) menjelaskan citra dapat ditanamkan dan disebarluaskan lewat segala media komunikasi. Pasaribu (2015) menyatakan bahwa penggunaan media internal mempunyai hubungan kuat dan positif terhadap citra perusahaan.

Sven Windahl dalam West dan Turner (2007) menyebut kombinasi dari teori Uses and Gratifications dan tradisi efek menjadi model Uses and Effect. Dalam teori Uses and Effect, kebutuhan hanya menjadi salah satu faktor dalam menentukan penggunaan media. Karakteristik individual, harapan dan persepsi terhadap media, serta tingkat aksesbilitas terhadap media memengaruhi keputusan penggunaan media (Windahl dalam Hamad et al. 2001).

Ketika menentukan efek media, teori Uses and Effect menganggap bahwa efek berasal sebagian dari penggunaan isi media (dengan pengguna sebagai mediator konten tersebut) dan sebagian lagi dari sifat penggunaan media tersebut. Dampak media terhadap konsumsi media oleh individu mengalir dari isi dan jenis media (efek) dan bagaimana penggunaannya (konsekuensi), sehingga kedua unsur tersebut

Menurut The Association of Certified Fraud Examiners (ACFE) dalam Sulastri dan Simanjuntak (2014), fraud adalah: "perbuatan-perbuatan yang melawan hukum yang dilakukan dengan sengaja untuk tujuan tertentu (manipulasi atau memberi laporan keliru terhadap pihak lain) dilakukan orang-orang dari dalam atau luar organisasi untuk mendapatkan keuntungan pribadi atau kelompok yang secara langsung atau tidak langsung merugikan pihak lain.

Pusat Pendidikan dan Pelatihan Pengawasan (Pusdiklatwas) BPKP merupakan salah satu unit kerja BPKP yang mempunyai tugas pokok 
melaksanakan penyelenggaraan, pembinaan dan koordinasi kegiatan pendidikan dan pelatihan di bidang pengawasan. Humas Pusdiklatwas BPKP menerbitkan majalah ilmiah triwulanan Kampus Pengawasan (KP) pada tahun 2015 dengan tujuan menjadi jembatan komunikasi dan pengembangan profesi pada diklat auditor Pusdiklatwas BPKP dan seluruh kalangan APIP se-Indonesia. Selain itu sebagai sarana publikasi kinerja yang telah dicapai untuk memelihara citra positif organisasi. Penelitian ini difokuskan kepada pengaruh majalah Kampus Pengawasan terhadap efek majalah berupa peningkatan pengetahuan dan sikap APIP terhadap Fraud, serta citra Pusdiklatwas BPKP di Bogor.

\section{Tujuan Penelitian}

Penelitian ini bertujuan untuk: (1) menguji pengaruh penggunaan media majalah KP terhadap perubahan pengetahuan dan sikap APIP tentang fraud, (2) menguji pengaruh penggunaan media majalah KP terhadap citra organisasi, (3) menganalisis pengaruh karakteristik pembaca, kebutuhan informasi, penilaian efektivitas majalah dan selektivitas terhadap peningkatan pengetahuan dan sikap APIP tentang fraud dan citra organisasi.

\section{Hipotesis}

Penelitian ini menguji tiga buah hipotesis penelitian yang diuji kebenarannya dalam penelitian ini yaitu :

(1) Terdapat perbedaan nyata efek majalah berupa peningkatan pengetahuan dan sikap APIP tentang fraud antara kelompok perlakuan dan kelompok kontrol;

(2) Terdapat perbedaan nyata citra organisasi berupa peningkatan citra lembaga dan peningkatan citra pengajar antara kelompok perlakuan dan kelompok kontrol;

(3) Terdapat pengaruh nyata karakteristik APIP, kebutuhan informasi, penilaian efektivitas majalah dan selektivitas terhadap efek majalah dan citra organisasi.

\section{METODE PENELITIAN}

\section{Desain}

Penelitian yang dilakukan adalah pendekatan penelitian kuantitatif dengan metode eksperimen subyek penelitian yang dipilih adalah APIP, yang merupakan peserta diklat pada Pusdiklatwas BPKP, sebagai kelompok yang sudah terbentuk secara alamiah dan partisipan tidak ditugaskan secara acak sehingga termasuk quasy experimental (Creswell 2012). Jenis desain penelitian eksperimental yang akan digunakan adalah Rancangan Kelompok-Kontrol (Pre-test dan post-test) Nonekuivalen atau Nonequivalent (Pre-test and Post-test) Control-Group Design terdiri dari kelompok perlakuan dan kelompok kontrol masing-masing terdiri dari dua kelas. 


\section{Lokasi dan Waktu Penelitian}

Lokasi penelitian di Pusdiklatwas BPKP Ciawi Bogor dan Hotel Indra Jaya Puncak merupakan tempat penyelenggaraan diklat Pembentukan Auditor Ahli. Waktu penelitan dilakukan selama dua bulan dari Maret hingga Mei 2016.

\section{Subyek Penelitian}

Subyek penelitian adalah APIP yang merupakan peserta diklat Pembentukan Auditor Ahli yang berasal dari Inspektorat Kab/Kota sebanyak 80 orang, terbagi pada dua kelas sebagai kelompok perlakuan dan dua lainnya sebagai kelompok kontrol. Pemilihan kelas dilakukan secara purposive dengan mempertimbangkan kesepadanan kelas yang memungkinkan untuk menjadi subyek penelitian pada waktu penelitian berlangsung.

\section{Teknik Pengumpulan Data dan Instrumentasi Penelitian}

Data yang dikumpulkan terdiri dari data primer dan sekunder. Data primer diperoleh melalui observasi, wawancara berkuesioner dan focus group discussion (FGD). Selain itu, juga dilakukan uji coba efektivitas rancangan media melalui kuesioner yang ditujukan kepada juri yang terdiri dari akademisi dan praktisi yang merupakan pakar di bidang komunikasi, media dan pengawasan. Sementara data sekunder diperoleh dari kantor Pusdiklatwas BPKP.

Instrumen yang digunakan dalam eksperimen berupa lembar pre-test dan post-test yang terdiri dari pengukuran pengetahuan menggunakan soal pilihan ganda, serta pengukuran sikap dan citra menggunakan skala Likert. Pengumpulan data berupa kuesioner yang menggunakan skala Likert terdiri dari empat bagian, yaitu karakteristik APIP, kebutuhan informasi, penilaian efektivitas majalah dan selektivitas.

\section{Analisis Data}

Analisis data dilakukan menggunakan teknik statistik deskriptif untuk memetakan karakteristik pembaca, kebutuhan informasi, penilaian efektivitas majalah dan selektifitas; uji komparatif Mann-Whitney untuk menguji perbedaan karakteristik APIP antara kelompok perlakuan dan kontrol serta analisis statistik inferensial untuk menguji tiga hipotesis penelitian, yaitu:

1. Uji t berpasangan (paired sample $t$ test) dengan membandingkan hasil pretest (sebelum mendapat perlakuan) dan post-test (setelah mendapat perlakuan) melalui majalah untuk menganalisis pengaruh perbedaan terhadap efek majalah berupa peningkatan pengetahuan, sikap dan citra organisasi yang ditimbulkan dari perlakuan.

2. Analisis Regresi dengan Software SPSS untuk mengetahui pengaruh karakteristik pembaca, kebutuhan informasi, penilaian efektivitas majalah dan selektifitas dengan efek majalah berupa peningkatan pengetahuan, sikap dan citra organisasi.

\section{Validitas dan Reliabilitas}

Validitas instrumen menggunakan analisis statistik product moment Pearson sebanyak 37 pernyataan valid $(0.416$ - 0.934) dan reliabilitas menggunakan alpha 
Cronbach's dengan nilai reliabilitas masing-masing; karakteristik 0.561, kebutuhan informasi 0.893 , penilaian efektivitas 0.838 , selektivitas 0.467 , sikap 0.810 dan citra 0.922 .

\section{HASIL DAN PEMBAHASAN}

\section{Karakteristik APIP}

Komposisi umur pada masing-masing kelompok bervariasi, pada kelompok Dengan Pemberian Majalah mayoritas pada kelompok umur 35 - 38 tahun sebesar 47.5 persen dan pada kelompok Tanpa Pemberian Majalah mayoritas pada kelompok umur 39 - 48 tahun sebesar 37.5 persen (Tabel 1).

Jenis kelamin pada kelompok Dengan Pemberian Majalah sebesar 55 persen merupakan laki-laki sedangkan pada kelompok Tanpa Pemberian Majalah sebesar 65 persen merupakan wanita. Pendidikan responden mayoritas sarjana pada kelompok Dengan Pemberian Majalah sebesar 82.50 persen sedangkan pada kelompok Tanpa Pemberian Majalah sebesar 75 persen.

Adapun penghasilan responden pada kelompok Dengan Pemberian Majalah didominasi pada kelompok penghasilan antara Rp4.100.000,00 hingga Rp8.000.000,00 sebesar 40 persen sedangkan pada kelompok Tanpa Pemberian Majalah didominasi pada kelompok penghasilan antara Rp3.100.000,00 hingga Rp4.000.000,00 sebesar 42.5 persen. Komitmen organisasi pada unit kerja Inspektorat mayoritas pada kategori tinggi masing-masing kelompok sebesar 52.5 persen, komitmen profesi pada jabatan auditor mayoritas pada kategori sedang, pada kelompok Dengan Pemberian Majalah sebesar 62.50 persen sedangkan pada kelompok Tanpa Pemberian Majalah sebesar 57.50 persen. Motivasi meningkatkan kompetensi mayoritas juga pada kategori sedang, pada kelompok Dengan Pemberian Majalah sebesar 70 persen sedangkan pada kelompok Tanpa Pemberian Majalah sebesar 55 persen. Uji Mann-Whitney menunjukkan terdapat perbedaan signifikan pada indikator umur dan jenis kelamin.

\section{Kebutuhan Informasi}

Hasil penelitian menunjukkan, kebutuhan informasi mengenai perkembangan pengetahuan di bidang pengawasan internal pada kategori tinggi (52.50 persen) dan kategori sedang (47.50 persen) sedangkan kebutuhan informasi mengenai perkembangan kebijakan dan peraturan pemerintah pada kategori tinggi (60 persen) dan kategori sedang (40 persen). Adapun kebutuhan informasi mengenai perkembangan profesi auditor internal pada kategori tinggi (52.50 persen), kategori sedang (45 persen) dan kategori rendah (2.50 persen) serta kebutuhan informasi mengenai hasil penelitian di bidang pengawasan pada kategori tinggi ( 50 persen), kategori sedang (45 persen) dan kategori rendah (5 persen). 
Tabel 1 Karakteristik APIP

\begin{tabular}{|c|c|c|c|c|c|c|c|}
\hline \multirow[b]{2}{*}{$\begin{array}{l}\text { Karakteristik } \\
\text { APIP }\end{array}$} & \multicolumn{2}{|c|}{$\begin{array}{c}\text { Dengan Pemberian } \\
\text { Majalah }(n=40)\end{array}$} & \multicolumn{2}{|c|}{$\begin{array}{c}\text { Tanpa Pemberian } \\
\text { Majalah }(n=40)\end{array}$} & \multicolumn{2}{|c|}{ Mean rank } & \multirow[t]{2}{*}{$\begin{array}{c}\mathrm{p} \\
\text { value }\end{array}$} \\
\hline & $\begin{array}{l}\text { Jumlah } \\
\text { (orang) }\end{array}$ & $\begin{array}{c}\text { Persentase } \\
\text { (\%) }\end{array}$ & $\begin{array}{l}\text { Jumlah } \\
\text { (orang) }\end{array}$ & $\begin{array}{c}\text { Persentase } \\
(\%)\end{array}$ & $\begin{array}{c}\text { Dengan } \\
\text { Pemberia } \\
\mathrm{n} \\
\text { Majalah }\end{array}$ & $\begin{array}{c}\text { Ianpa } \\
\text { Pember } \\
\text { ian } \\
\text { Majala } \\
\text { h }\end{array}$ & \\
\hline Umur (tahun) & & & & & 33.11 & 47.89 & $\begin{array}{r}0.004^{*} \\
*\end{array}$ \\
\hline $27-34$ & 16 & 40.00 & 11 & 27.50 & & & \\
\hline $35-38$ & 19 & 47.50 & 14 & 35.00 & & & \\
\hline $39-48$ & 5 & 12.50 & 15 & 37.50 & & & \\
\hline Jenis Kelamin & & & & & 36.50 & 44.50 & $0.074 *$ \\
\hline Laki-laki & 22 & 55.00 & 14 & 35.00 & & & \\
\hline Wanita & 18 & 45.00 & 26 & 65.00 & & & \\
\hline Pendidikan & & & & & 38.00 & 43.00 & 0.192 \\
\hline Sarjana & 33 & 82.50 & 30 & 75.00 & & & \\
\hline Pascasarjana & 7 & 17.50 & 10 & 25.00 & & & \\
\hline \multicolumn{3}{|c|}{ Penghasilan (rupiah/bulan) } & & & 44.25 & 36.75 & 0.145 \\
\hline 2- 3 juta & 15 & 37.50 & 16 & 40.00 & & & \\
\hline 3.1- 4 juta & 9 & 22.50 & 17 & 42.50 & & & \\
\hline 4.1- 8 juta & 16 & 40.00 & 7 & 17.50 & & & \\
\hline $\begin{array}{l}\text { Komitmen Organ } \\
\text { Sedang }=60 \text { s.d. }\end{array}$ & & & & & 40.74 & 40.26 & 0.922 \\
\hline 80 & 19 & 47.50 & 19 & 47.50 & & & \\
\hline Tinggi $=>80$ & 21 & 52.50 & 21 & 52.50 & & & \\
\hline $\begin{array}{l}\text { Komitmen } \\
\text { Profesi } \\
\text { Sedang=60 }\end{array}$ & & & & & 40.41 & 40.59 & 0.972 \\
\hline s.d. 80 & 25 & 62.50 & 23 & 57.50 & & & \\
\hline Tinggi $=>80$ & 15 & 37.50 & 17 & 42.50 & & & \\
\hline \multicolumn{3}{|c|}{ Motivasi Meningkatkan Kompetensi } & & & 38.51 & 42.49 & 0.426 \\
\hline Rendah $=<60$ & 1 & 2.50 & 1 & 2.50 & & & \\
\hline $\begin{array}{l}\text { Sedang }=60 \text { s.d. } \\
80\end{array}$ & 28 & 70.00 & 22 & 55.00 & & & \\
\hline Tinggi $=>80$ & 11 & 27.50 & 17 & 42.50 & & & \\
\hline
\end{tabular}

\section{Penilaian Efektivitas Majalah}

Penilaian efektivitas majalah secara keseluruhan pada indiktor daya tarik pada kategori tinggi (30 persen), kategori sedang (67.5 persen) dan kategori rendah (2.5 persen). Pada indikator pemahaman pada kategori tinggi (22.5 persen), kategori sedang (75 persen) dan kategori rendah (2.5 persen). Penilaian efektivitas majalah pada indikator keterlibatan diri pada kategori tinggi (17.5 persen), kategori sedang (77.5 persen) dan kategori rendah (5 persen), untuk indikator penerimaan secara keseluruhan pada kategori tinggi (30 persen) dan kategori sedang (70 persen). 


\section{Selektivitas}

Hasil penelitian secara keseluruhan menunjukkan tingkat selektivitas responden cukup tinggi, dimana frekuensi membaca pada kategori sedang (40 persen) dan kategori rendah (60 persen), serta jumlah artikel yang dibaca pada kategori sedang ( 25 persen) dan kategori rendah ( 75 persen).

\section{Pengetahuan APIP}

Peningkatan pengetahuan APIP dari 15 pertanyaan pada kelompok Dengan Pemberian Majalah 39 (rataan 0.98) dari pengetahuan awal 251 (rataan 6.28) termasuk kategori rendah. Pada kelompok Tanpa Pemberian Majalah justru terjadi penurunan 13 (rataan -0.33) dari pengetahuan awal 235 (rataan 5.88). Hal ini disajikan pada Tabel 2.

Tabel 2. Peningkatan pengetahuan APIP

\begin{tabular}{|c|c|c|c|c|}
\hline \multirow[t]{2}{*}{ Pengetahuan } & \multicolumn{2}{|c|}{ Dengan Pemberian Majalah } & \multicolumn{2}{|c|}{ Tanpa Pemberian Majalah } \\
\hline & Total Skor & Rataan & Total Skor & Rataan \\
\hline Pengetahuan Awal & 251 & 6.28 & 235 & 5.88 \\
\hline Pengetahuan Akhir & 290 & 7.25 & 222 & 5.55 \\
\hline Peningkatan & 39 & 0.98 & -13 & -0.33 \\
\hline
\end{tabular}

Tabel 3. Uji t berpasangan peningkatan pengetahuan pada kelompok Dengan Pemberian Majalah

\begin{tabular}{cccc}
\hline & Nilai Rata-rata & & Uji t berpasangan \\
\hline Pre-test & Post-test & Selisih & Nilai t Hitung \\
\hline 6.28 & 7.25 & 0.98 & $2.831^{*}$ \\
\hline
\end{tabular}

Berdasarkan Tabel 3, hasil uji t berpasangan pada kelompok Dengan Pemberian Majalah dengan nilai thitung $2.831>$ dari t tabel $2.042(\alpha=0.05)$, hal ini menunjukkan bahwa terdapat peningkatan pengetahuan yang nyata sebagai akibat pemberian majalah. Walaupun masih berkategori rendah, majalah KP mampu menjadikan responden sebagai APIP semakin mengetahui istilah red flag sebagai gejala terjadinya fraud, unit kerja yang melakukan penilaian tingkat risiko dan upayamitigasi atas risikokecurangan secara periodik, definisi fraud, faktor yang berkontribusi paling besar dalam mengungkap kecurangan organisasi maupun perbedaan tingkatan korupsi sebagai salah satu bentuk fraud.

Namun peningkatan pengetahuan masih berkategori rendah (rataan 0.98) karena frekuensi membaca dan jumlah artikel yang dibaca masih rendah. Hal ini disebabkan jadwal diklat yang padat dan materi diklat yang dinilai cukup berat. Selain itu, sebagian APIP juga menilai daya tarik majalah masih harus ditingkatkan.

\section{Sikap APIP}

Skor peningkatan sikap responden dari sepuluh pernyataan pada kelompok Dengan Pemberian Majalah 69.84 (rataan 1.75) dari sikap awal 1642 (rataan 41.05) yang termasuk berkategori tinggi. Pada kelompok Tanpa Pemberian 
Majalah justru mengalami penurunan -1.34 (rataan -0.03) dari sikap awal 1636.51 (rataan 40.91). Hal ini disajikan pada Tabel 4.

Tabel 4. Peningkatan sikap APIP

\begin{tabular}{|c|c|c|c|c|}
\hline \multirow[t]{2}{*}{ Sikap } & \multicolumn{2}{|c|}{ Dengan Pemberian Majalah } & \multicolumn{2}{|c|}{ Tanpa Pemberian Majalah } \\
\hline & Total Skor & Rataan & Total Skor & Rataan \\
\hline Sikap Awal & 1642.00 & 41.05 & 1636.51 & 40.91 \\
\hline Sikap Akhir & 1711.84 & 42.80 & 1635.17 & 40.88 \\
\hline Peningkatan & 69.84 & 1.75 & -1.34 & -0.03 \\
\hline
\end{tabular}

Tabel 5. Uji t berpasangan peningkatan sikap pada kelompok Dengan Pemberian Majalah

\begin{tabular}{cccc}
\hline & Nilai Rata-rata & \multicolumn{2}{c}{ Uji t berpasangan } \\
\hline Pre-test & Post-test & Selisih & Nilai t Hitung \\
\hline 41.05 & 42.80 & 1.75 & $3.077^{*}$ \\
\hline
\end{tabular}

*berbeda nyata pada $\alpha=0.05$

Hasil uji t berpasangan pada kelompok Dengan Pemberian Majalah dengan nilai thitung $3.077>$ dari ttabel $2.042(\alpha=0.05)$. Hal ini menunjukkan terdapat peningkatan sikap yang nyata. Peningkatan sikap terutama pada keyakinan bahwa APIP harus mampu memberikan jaminan bahwa seluruh sistem pengendalian fraud berjalan efektif serta deteksi kasus korupsi berjamaah dapat ditingkatkan dengan mekanisme whistleblowing, jaminan bagi pengadu dan jaminan penanganan pengaduan secara transparan. Selain itu responden sebagai APIP juga semakin meyakini bahwa perubahan gaya hidup auditee harus menjadi perhatian APIP dan harus menjadi dasar evaluasi lebih mendalam terhadap sistem pengendalian atas risiko fraud.

Berdasarkan data di atas, hipotesis pertama pada penelitian ini diterima. Hal ini terlihat dari adanya perbedaan pengetahuan dan sikap tentang fraud yang nyata pada APIP kelompok perlakuan dibandingkan kelompok kontrol sehingga dapat disimpulkan bahwa pemberian majalah KP pada kelompok perlakuan mampu meningkatkan efek majalah berupa pengetahuan dan sikap APIP tentang fraud. Hal ini relevan dengan penelitian Yusnita (2015) yang menyatakan media booklet mampu meningkatkan pengetahuan tentang pembuatan pupuk organik cair pada anak-anak dan penelitian Labbe dan Fortner (2001) mengenai majalah lingkungan $E / T h e$ Environmental Magazine yang menyimpulkan pelanggan menggunakan majalah sebagai alat memperkuat keyakinan dan nilai atau penggunaan untuk identitas pribadi, serta setidaknya untuk memperkuat kebiasaan yang telah ada.

\section{Citra Profesionalitas Lembaga}

Skor peningkatan citra lembaga oleh responden dari tiga pernyataan pada kelompok Dengan Pemberian Majalah 3 (rataan 0.07) dari skor awal 529 (rataan 13.23) termasuk berkategori tinggi dan kelompok Tanpa Pemberian Majalah terjadi peningkatan 5 (rataan 0.12) dari skor awal 539 (rataan 13.48). Hal ini disajikan pada Tabel 6. 
Tabel 6. Peningkatan citra lembaga

\begin{tabular}{lrrrr}
\hline & \multicolumn{2}{c}{ Dengan Pemberian Majalah } & \multicolumn{2}{c}{ Tanpa Pemberian Majalah } \\
\cline { 2 - 5 } Citra Profesionalitas Lembaga & Total Skor & Rataan & Total Skor & Rataan \\
\hline Citra Awal & 529 & 13.23 & 539 & 13.48 \\
Citra Akhir & 532 & 13.30 & 544 & 13.60 \\
Peningkatan & 3 & 0.07 & 5 & 0.12 \\
\hline
\end{tabular}

Tabel 7 Uji t berpasangan peningkatan citra lembaga pada kelompok Dengan Pemberian Majalah

\begin{tabular}{ccccc}
\hline & Nilai rata-rata & \multicolumn{2}{c}{ Uji T Berpasangan } \\
\hline Pre-test & Post-test & \multicolumn{2}{c}{ Selisih } & Nilai t Hitung \\
\hline 13.23 & 13.30 & 0.07 & & $0.476^{\text {tn }}$
\end{tabular}

${ }^{\text {tn }}$ tidak berbeda nyata $(\alpha=0.05)$

Berdasarkan Tabel 7 di atas, hasil uji t berpasangan pada kelompok Dengan Pemberian Majalah pada nilai t hitung $0.476<$ dari t tabel $2.042(\alpha=0.05)$. Hal ini menunjukkan bahwa tidak terdapat peningkatan citra lembaga yang nyata. Skor citra lembaga yang cukup tinggi pada saat pretes, sebagian ada yang naik dan sebagian lagi turun pada saat postes sehingga secara keseluruhan tidak terdapat peningkatan citra yang nyata.

\section{Citra Profesionalitas Pengajar}

Skor peningkatan citra pengajar oleh responden dari dua pernyataan pada kelompok Dengan Pemberian Majalah 3 (rataan 0.07) dari citra pengajar awal 363 (rataan 9.08) termasuk berkategori tinggi. Pada kelompok Tanpa Pemberian Majalah justru mengalami penurunan -5 (rataan -0.12 ). Hal ini disajikan pada Tabel 8.

Tabel 8. Peningkatan citra pengajar

\begin{tabular}{|c|c|c|c|c|}
\hline \multirow[t]{2}{*}{ Citra Pengajar } & \multicolumn{2}{|c|}{ Dengan Pemberian Majalah } & \multicolumn{2}{|c|}{ Tanpa Pemberian Majalah } \\
\hline & Total Skor & Rataan & Total Skor & Rataan \\
\hline Citra Awal & 363 & 9.08 & 360 & 9.00 \\
\hline Citra Akhir & 366 & 9.15 & 355 & 8.88 \\
\hline Peningkatan & 3 & 0.07 & -5 & -0.12 \\
\hline
\end{tabular}

Tabel 9. Uji t berpasangan peningkatan citra pengajar pada kelompok Dengan Pemberian Majalah

\begin{tabular}{cccc}
\hline & Nilai rata-rata & \multicolumn{2}{c}{ Uji T Berpasangan } \\
\hline Pre-test & Post-test & Selisih & Nilai t Hitung \\
\hline 9.08 & 9.15 & 0.07 & $0.476^{\text {tn }}$ \\
\hline
\end{tabular}

${ }^{\text {tn }}$ tidak berbeda nyata $(\alpha=0.05)$

Tabel 9 menunjukan hasil uji t Berpasangan pada kelompok Dengan Pemberian Majalah dengan nilai thitung $0.476<$ dari ttabel $2.042(\alpha=0.05)$. Hal ini membuktikan tidak terdapat peningkatan yang nyata. 
Dilihat dari Tabel 7 dan 9, maka hipotesis kedua pada penelitian ditolak. Hal ini terlihat dari tidak adanya perbedaan citra yang nyata pada APIP kelompok perlakuan dibandingkan kelompok kontrol, sehingga dapat disimpulkan pemberian majalah KP sebagai media internal semi eksternal pada kelompok perlakuan belum mampu meningkatkan citra organisasi, baik pada profesionalisme lembaga maupun pengajar. Hal ini berbeda dengan penelitian Pasaribu (2015) dimana media internal berupa portal mampu meningkatkan citra organisasi. Hal ini dapat diakibatkan adanya perbedaan karakteristik dimana media portal khusus sebagai media kehumasan sedangkan majalah KP berfungsi ganda yaitu sebagai majalah ilmiah sekaligus majalah kehumasan dengan konten kehumasan yang masih minim.

Penelitian Kiousis et al.(2007) menyatakan terdapat beberapa atribut untuk mengukur pengaruh agenda-building dan agenda-setting pemberitaan di media massa terhadap reputasi perusahaan yang dapat menjadi rujukan dalam memperkaya konten kehumasan majalah KP yaitu meliputi produk dan layanan, kinerja keuangan, lingkungan tempat kerja, tanggung jawab sosial, visi dan kepemimpinan serta hubungan emosional.

\section{Hasil Analisis Regresi: Pengaruh Karakteristik APIP, Kebutuhan Informasi, Penilaian Efektivitas Majalah dan Selektivitas terhadap Efek Majalah serta Citra Organisasi}

\section{Pengaruh Karakteristik APIP terhadap Efek Majalah dan Citra Organisasi}

Tabel 10 menunjukkan nilai koefisien regresi indikator komitmen organisasi sebesar 10.504 berpengaruh nyata terhadap efek majalah berupa peningkatan pengetahuan. Semakin tinggi komitmen organisasi responden maka semakin meningkat pengetahuan yang diperoleh dengan membaca majalah KP. APIP menganggap unit kerja Inspektorat merupakan unit kerja yang strategis karena berfungsi sebagai pengawas internal bagi unit kerja lain. Sebagian responden bahkan mengajukan diri untuk pindah ke Inspektorat karena berharap dapat lebih meningkatkan idealisme dan profesionalisme.

Indikator lain pada peubah karakteristik APIP yaitu penghasilan terbukti berpengaruh nyata terhadap efek majalah berupa peningkatan sikap. Semakin tinggi penghasilan responden akan meningkatkan independensi sebagai auditor internal sehingga semakin meningkatkan sikap terhadap upaya pencegahan dan deteksi fraud. Walaupun besaran gaji sebagai PNS sama namun besaran tunjangan berbeda-beda sesuai APBD masing-masing daerah.

Indikator motivasi meningkatkan kompetensi juga terbukti berpengaruh nyata terhadap efek majalah berupa peningkatan sikap. Motivasi yang tinggi akan menggerakkan APIP untuk meningkatkan kompetensi melalui berbagai hal baik mengikuti diklat, seminar, workshop maupun mengakses media. Responden menyadari pentingnya kompetensi dalam mendukung penugasan yang bersifat dinamis serta untuk kemajuan karirnya sebagai APIP.

Peubah karakteristik APIP berpengaruh nyata terhadap citra berupa profesionalitas lembaga, yaitu pada indikator komitmen organisasi dengan koefisien regresi sebesar 4.103. Semakin tinggi komitmen organisasi responden 
semakin besar peningkatan citra profesionalitas lembaga. Hal ini didukung kerjasama yang baik antara Pusdiklatwas BPKP dengan Inspektorat khususnya dalam peningkatan kapabilitas APIP melalui penyelenggaraan diklat.

\section{Pengaruh Kebutuhan Informasi terhadap Efek Majalah dan Citra Organisasi}

Kebutuhan informasi tidak berpengaruh terhadap efek majalah baik pada peningkatan pengetahuan maupun sikap. Demikian pula terhadap citra baik citra profesionalitas lembaga maupun pengajar. Hal ini disebabkan kebutuhan informasi semua responden secara homogen tergolong tinggi pada semua jenis informasi serta telah tersedianya sumber informasi lain selain majalah baik berupa buku, pedoman, peraturan dsb.

Kebutuhan informasi tertinggi pada kebijakan dan peraturan, diikuti pengetahuan mengenai pengawasan internal dan perkembangan profesi auditor internal, dan terakhir hasil penelitian. APIP menyatakan pentingnya pengetahuan mengenai kebijakan dan peraturan pemerintah karena banyaknya peraturan perundang-undangan yang baru dan sering tumpang tindih dengan peraturan perundang-undangan sebelumnya. Hal tersebut membutuhkan kajian yang mendalam agar auditor mampu memahami secara menyeluruh dan menjadikannya sebagai pedoman dalam melakukan audit.

Pengetahuan mengenai pengawasan internal juga sangat dibutuhkan responden mengingat perkembangannya yang sangat dinamis. Adapun kebutuhan informasi mengenai profesi auditor internal juga dianggap penting untuk menunjang pengembangan karir dan kompetensi auditor. Selain itu ketersediaan media sejenis yang masih sangat jarang menjadikan tingginya kebutuhan tersebut. Kebutuhan informasi mengenai hasil penelitian juga dinilai penting untuk mendukung keterkaitan teori dengan implementasi di lapangan. 
Tabel 10.Pengaruh karakteristik APIP, kebutuhan informasi, penilaian efektivitas majalah serta selektivitas terhadap efek majalah dan citra organisasi

\begin{tabular}{|c|c|c|c|c|}
\hline \multirow[t]{2}{*}{ Peubah Bebas } & \multicolumn{2}{|c|}{ Efek majalah KP( $\beta)$} & \multicolumn{2}{|c|}{ Citra organisasi $(\beta)$} \\
\hline & Pengetahuan & Sikap & Lembaga & Pengajar \\
\hline \multicolumn{5}{|l|}{ Karakteristik APIP } \\
\hline Umur & 0.024 & -0.267 & -0.055 & -0.042 \\
\hline Jenis kelamin & 0.359 & -2.108 & -0.015 & -0.162 \\
\hline Pendidikan & -0.070 & -0.923 & -0.382 & -0.406 \\
\hline Penghasilan & 0.033 & $0.002 * *$ & 0.019 & 0.007 \\
\hline Komitmen organisasi & $10.504^{* *}$ & -1.757 & $4.103^{* *}$ & 1.840 \\
\hline Komitmen profesi & 0.663 & 9.579 & -1.579 & -1.558 \\
\hline $\begin{array}{l}\text { Motivasi meningkatkan } \\
\text { kompetensi }\end{array}$ & 4.872 & $21.352 * *$ & -0.718 & 1.475 \\
\hline \multicolumn{5}{|l|}{ Kebutuhan informasi } \\
\hline Pengawasan internal & -4.778 & 1.552 & 2.625 & 2.962 \\
\hline Profesi auditor internal & 5.748 & 16.654 & 1.589 & -2.472 \\
\hline Kebijakan pemerintah & 4.084 & -3.115 & -3.581 & -1.371 \\
\hline \multirow[t]{2}{*}{ Hasil penelitian pengawasan } & 0.178 & - & -0.589 & -0.292 \\
\hline & & 12.830 & & \\
\hline \multicolumn{5}{|l|}{ Penilaian efektivitas majalah } \\
\hline Daya tarik & $8.746 * *$ & 12.498 & 2.251 & 0.547 \\
\hline Pemahaman & 0.697 & $13.883^{*}$ & 1.697 & 0.189 \\
\hline Keterlibatan diri & -1.655 & 7.067 & 0.264 & 1.613 \\
\hline Penerimaan & -0.218 & 9.908 & -0.024 & 1.874 \\
\hline \multicolumn{5}{|l|}{ Selektivitas } \\
\hline Frekuensi membaca & $0.278 * *$ & 0.881 & -0.208 & -0.282 \\
\hline Jumlah artikel & $0.301 * *$ & 1.188 & 0.064 & 0.130 \\
\hline \multicolumn{2}{|c|}{$\begin{array}{l}\text { Keterangan: **berpengaruh nyata pada } \mathrm{p} \leq 0.05 \\
\text { sederhana } \\
\\
* \text { berpengaruh nyata pada } \mathrm{p} \leq 0.1\end{array}$} & $\beta=\mathrm{kc}$ & fisien regresi li & near \\
\hline
\end{tabular}

\section{Pengaruh Penilaian Efektivitas Majalah terhadap Efek Majalah dan Citra}

Penilaian efektivitas majalah berpengaruh nyata terhadap efek majalah khususnya indikator daya tarik terhadap peningkatan pengetahuan dengan nilai koefisien regresi sebesar 8.746 ( $p$-value 0.05). Walaupun secara keseluruhan penilaian responden cukup baik namun sebagian responden mengaku penyampaian dalam bahasa ilmiah kurang menarik. Penggunaan bahasa ilmiah populer dapat menjadi alternatif. Hal ini relevan dengan pernyataan Wijana (2013) bahwa untuk mewadahi kalangan yang ingin menikmati informasi ilmiah dalam situasi yang agak santai dengan bahasa yang tidak terlalu ketat mematuhi norma yang terlalu formal penulis perlu mengkreasikan jenis wacana tertentu yang lazim disebut wacana ilmiah populer.

Responden juga mengharapkan peningkatan kualitas desain majalah khususnya cover dan headline. Ilustrasi pada media publikasi telah menjadi bentuk penyampaian pesan lewat bertutur secara visual yang lebih kuat daripada tulisan serta dapat membangun persepsi bagi yang melihatnya, khususnya ilustrasi pada sampul muka merupakan pemberi identitas sekaligus penarik perhatian sehingga membutuhkan sinergi antara penulis dengan seniman (Adi 2014). 
Indikator pemahaman juga terbukti berpengaruh nyata terhadap peningkatan sikap. Pemahaman APIP terhadap teori dan perkembangan fraud yang disajikan pada majalah KP cukup baik, hal tersebut karena didukung penyampaian narasi dan penggunaan tabel, matriks maupun ilustrasi yang dinilai cukup jelas. Namun peubah penilaian efektivitas majalah terbukti tidak berpengaruh nyata terhadap peningkatan citra baik citra profesionalitas lembaga maupun pengajar.

\section{Pengaruh Selektivitas terhadap Efek Majalah dan Citra Organisasi}

Peubah selektivitas berpengaruh sangat nyata terhadap efek majalah yaitu pada peningkatan pengetahuan namun tidak berpengaruh nyata pada sikap serta terhadap citra baik peningkatan citra profesionalitas lembaga maupun pengajar. Selektivitas pembaca secara keseluruhan masih tinggi dimana frekuensi membaca dan jumlah artikel yang dibaca masih rendah yang disebabkan padatnya jadwal diklat. Pemberian majalah KP hanya pada saat diklat masih kurang efektif sehingga perlu diunggah pada media lain baik website maupun media sosial agar dapat diakses sewaktu-waktu dan menjangkau lebih banyak pembaca.

Dari analisis regresi yang dikemukakan, terlihat hipotesis ketiga pada penelitian ini diterima. Hal ini dibuktikan dengan adanya pengaruh karakteristik APIP, penilaian efektivitas majalah dan selektivitas kelompok perlakuan terhadap efek majalah berupa peningkatan pengetahuan dan sikap APIP tentang fraud serta pengaruh karakteristik APIP terhadap citra yaitu peningkatan profesionalitas lembaga.

Penelitian ini mendukung teori uses and effect bahwa media mampu memberikan efek khususnya pada peningkatan pengetahuan dan sikap pembaca serta terdapat beberapa peubah yang turut berpengaruh terhadap efek majalah yaitu karakteristik pembaca, penilaian efektivitas majalah dan selektivitas.

\section{SIMPULAN}

Terdapat perbedaan efek majalah berupa peningkatan pengetahuan dan sikap APIP tentang fraud secara nyata antara kelompok perlakuan majalah KP dibanding kelompok kontrol. Tidak terdapat perbedaan citra organisasi berupa peningkatan profesionalitas lembaga dan pengajar secara nyata antara kelompok perlakuan majalah KP dibanding kelompok kontrol. Terdapat pengaruh nyata karakteristik APIP, penilaian efektivitas majalah dan selektivitas kelompok perlakuan terhadap efek majalah, serta karakteristik APIP terhadap citra organisasi.

\section{DAFTAR PUSTAKA}

Adi D. 2014. Memaknai bahasa visual pada ilustrasi bergambar Soeharto di sampul muka majalah Tempo. Humaniora. 5(2):612-623.

Anugerah R. 2014. Peranan Good Corporate Governance dalam pencegahan fraud. Jurnal Akuntansi. 3(1):101-113. 
Bagia IW, Yudiaatmaja F, Yulianthini NY. 2015. Model konseptual kinerja individual pegawai pemerintah daerah kabupaten yang berbasis kompetensi, komitmen organisasi dan motivasi kerja. Jurnal IImu Sosial dan Humaniora. 4(1):509-522.

Bertrand J. 1978. Communications Pretesting. Chicago[US]:The Community and Family Study Center, The University of Chicago.

Black J, Bryant J, Thompson S. 1998. Introduction Media Communication. New York[US]: Mc Graw Hills.

Creswell JW. 2012. Research Design: Pendekatan Kualitatif, Kuantitatif, dan Mixed. Yogyakarta[ID]: Pustaka Pelajar.

Denham BE. 2006. Effects of mass communication attitudes toward anabolic steroids: an analysis of high school seniors. Journal of Drug Issues.[internet]. [Diunduh pada 2015 Nov 24]. Tersedia pada: http://jod.sagepub.com/content/36/4/809.

Erina C, Darwanis, Zein B. 2012. Pengaruh integritas, obyektivitas, kerahasiaan dan kompetensi terhadap kinerja aparat pengawasan internal pemerintah (Studi pada Inspektorat Aceh). Jurnal Akuntansi Pascasarjana Universitas Syiah Kuala.2(1):15-27.

Fuad K. 2015. Pengaruh independensi, kompetensi, dan prosedur audit terhadap tanggungjawab dalam pendeteksian fraud. Jurnal Dinamika Akuntansi. 7(1):10-17.

Hamad I, Ichtiat HQ, Zulham. 2001. Political educations through the mass media? a survey of Indonesian University students. Asia Pasific Media Educator Issue. No.11:55-71.

Jefkins F, Yadin D. 2014. Public Relations. Edisi Kelima. Jakarta[ID]: Erlangga.

Kiousis S, Popescu C, Mitrook M. 2007. Understanding influence on corporate reputation: an examination of public relations efforts, media coverage, public opinion, and financial performance from an agenda-building and agenda-setting perspective. Journal of Public Relations Research. 19(2):147165.

Labbe CP, Fortner RW. 2001. Perceptions of the concerned reader: an analysis of The Subscribers of E/The Environmental Magazine. The Journal of Environmental Education. 32(3):41-46.

Nova F. 2011. Crisis Public Relations. Jakarta[ID]: PT Raja Grafindo Persada.

Pankratow M, Berry TR, Mc Hugh TF. 2013. Effect of reading health and appearance exercise magazines articles on perceptions of attractiveness and reasons for exercise. PloS ONE 8(4):e61894. DOI: 10.1371/journal.pone.0061894

Pasaribu Z. 2015. Pengaruh penggunaan media internal Portal PT Dirgantara Indonesia terhadap citra perusahaan. Jurnal Sosioteknologi. 4(1):61-70. 
Pickett K.H.S. 2003. The Internal Auditing Handbook. Hoboken, New Jersey[US]: John W. Wiley \& Sons, Inc.

Prawati B. 2003. Keterpakaian koleksi majalah ilmiah Pusat Perpustakaan dan Penyebaran Teknologi Pertanian oleh peneliti Badan Litbang Pertanian. Jurnal Perpustakaan Pertanian. 12(1):26-31.

Sardi. 2012. Tingkat adopsi artikel topik dan efek komunikasi majalah pertanian (kasus pembaca Majalah Trubus di Jakarta Selatan). [tesis]. Bogor[ID]: IPB.

Simanjuntak BH, 2015. Grand Design Peningkatan Kapabilitas APIP. Rakornas Pengawasan Intern Pemerintah Tahun 2015.13 Mei 2015. Jakarta: BPKP.[Internet]. [Diunduh pada 2015 Nov 15]. Tersedia pada: http://apip.bpkp.go.id/kapabilitasapip/

Sulastri, Simanjuntak BH. 2014. Fraud pada sektor pemerintah berdasarkan faktor keadilan kompensasi, sistem pengendalian internal, dan etika organisasi pemerintah (studi empiris dinas pemerintah Provinsi DKI Jakarta). e-journal Magister Akuntansi Trisakti. 1(2):199-227.

Tambunan K. 2014. Pemetaan majalah ilmiah terbitan Indonesia. Jurnal Dokumentasi dan Informasi.35(1):41-52.

Tranggono RP, Kartika A. 2008. Pengaruh komitmen organisasional dan profesional terhadap kepuasan kerja auditor dengan motivasi sebagai variabel intervening. Jurnal Bisnis dan Ekonomi. 15(1):80-90.

West R, Turner L. 2007. Introducing Communication Theory; Analysis and Application. Third Edition. New York[US]: Mc GrawHill.

Wibowo T. 2012. Hallmark Profesionalisme APIP di Indonesia. Majalah Warta Pengawasan. 19(3):11-16.

Wijana IDP. 2013. Pemakaian Bahasa dalam Karya Ilmiah Populer.Jurnal Arbitrer. $1(1): 19-36$

Yusnita T. 2015. Pengaruh visualisasi dan isi caption pada buklet pembuatan pupuk organik cair terhadap peningkatan pengetahuan siswa di Kota Bogor. Jurnal Komunikasi Pembangunan. 13(1):1-10. 